\title{
Introduction, Summary, and Some Inferences
}

\author{
Kung-Chung Liu and Uday S. Racherla
}

\begin{abstract}
India and China make a perfect comparison pair in the area of IT industry, with each having its unique strength and potential for cooperation and synergy. Due to heavy involvement of Indian IT firms in software outsourcing arrangement by MNEs, the IP or patent resources are not important. This is especially true when compared with Chinese IT firms, which have much larger patenting volume (compared with other manufacturing sectors). Film industry in India and China has grown despite piracy. In other words, it prospered with little or no copyright protection. More importantly, piracy in China and India did not kill the content industry, film and music alike, but probably helped in building the customer base and cultivating future demand, which might not be true for a small economy with a sophisticated audience such as Hong Kong. India can look at China to find IT means for delivery and payment of cinematographic content. India and China make a perfect comparison pair in the pharmaceutical industry as well. This time around, China can learn much from India. Although there is an increase in the number of patented drugs in the pharmaceutical industry in China, patents have made relatively low contribution to the industrial value, and IP held by Chinese
\end{abstract}

Special thanks to two of the first author's PhD students at Renmin University of China, Zhang Haoran and Liu Jianchen, and Professor He Jun, Graduate School at Shenzhen, Tsinghua University, for their help in collecting and analyzing relevant materials.

K.-C. Liu ( $\square)$

Renmin University of China, Beijing, China

Singapore Management University, Singapore, Singapore

e-mail: kcliu@smu.edu.sg

U. S. Racherla

Indian Institute of Technology Kanpur, Kanpur, Uttar Pradesh, India

e-mail: udays@ iitk.ac.in 
firms is less competitive compared with that of foreign companies. In contrast, major Indian generic companies continue to invest sizeable shares of their sales turnover in $\mathrm{R} \& \mathrm{D}$, which was manifest in their patenting behavior. They were more active in filing patent applications in foreign jurisdictions, but significantly less so in domestic patenting. The Indian automobile industry's absorption of global best practices has been slower than its Chinese counterpart. Strategies of firms in the Chinese auto industry provided a boost to technological learning more quickly and broadly than in India, especially in the electric vehicle sector. India can benefit from learning from China. IP has a relatively limited role in the development of the automobile industry in India and China.

\section{Keywords}

Film · IT · Pharmaceutical · Sharing economy · Automobile · Plant varieties · IP $\cdot$ Innovation $\cdot$ India $\cdot$ China

\section{$1 \quad$ Background}

In October 2014, ARCIALA held a workshop on "The Actual Role of IP in the Technological and Business Innovation in India and China” with an aim of bridging the monolithic elephant and dragon. This workshop was the first of its kind, though small in scale, and led to the publication of the book Innovation and IPRs in China and India-Myths, Realities and Opportunities in 2016. ${ }^{1}$ It was felt that the topic is worth further exploration.

As a follow-up ARCIALA co-hosted a 2-day workshop with Renmin University of China, Jindal Global University (New Delhi, India), and the German Max Planck Institute for Innovation and Competition on "Innovation, Economic Development and IP in India and China" on September 27 and 28, 2016, with expanded ambit and refreshed focus. This workshop was more of a preparatory nature, as it was about searching for a research framework, topics, questions, and approaches.

The workshop strived to examine the development of industries which are reflective of the innovation and economic development of the two giant economies or of vital importance to them. During that examination, it was asked why certain industries have developed in one country and not in the other and what role state innovation policy and/or IP policy has played. Is it causal, facilitating, crippling, co-relational, or simply irrelevant? What can India and China learn from each other, and is there any possibility of synergy, especially given that China is aging rapidly while half of the population of India is under $25 ?^{2}$

\footnotetext{
${ }^{1}$ Kung-Chung Liu/Uday S. Racherla (ed.), Innovation and IPR in China and India—Myth, Realities and Opportunities, Springer 2016.

${ }^{2}$ According to Wikipedia (https://en.wikipedia.org/wiki/Demographics_of_India), more than 50\% of India's population are below the age of 25 and more than $65 \%$ are below the age of 35 . It is expected that, in 2020, the average age of an Indian will be 29 years, compared to 37 for China and
} 
Six topics for this workshop were chosen: Innovation and IPR Policy, Open Innovation: Peer Production and the Sharing Economy, Film Industry, Software Industry, Pharmaceutical Industry and Developments in the Protection of Plant Varieties and Food Security. The width and depth of this study went beyond the domain of legal academics. Therefore, economists and management professors were invited to speak as well.

After the workshop, it was recognized that a solid empirical study on one specific industry in India and China should be first conducted as a pilot project, which can serve as a model for other study groups on different industries. The information technology (IT) industry was chosen ${ }^{3}$ given its vital importance to innovation and economic development in China and India. This pilot project was funded by the Max Planck Institute for Innovation and Competition and set out to answer the following questions:

(1) Why have IT services, business process outsourcing (BPO)/business process management (BPM), and the software industry developed in India and not in China?

(2) Why has the hardware industry developed in China and not in India?

(3) What role has state innovation policy played? Is it causal, facilitating, crippling, co-relational or simply irrelevant?

(4) What role has national IT infrastructure played?

(5) What role has IT sui generis legislation played?

(6) What role has IP (national policy, laws, rights, and adjudicated cases) played? Is it causal, facilitating, crippling, co-relational, or simply irrelevant?

(7) What can India and China learn from each other?

In addition, we have convened another six study groups to continue our research topics of the 2016 workshop with recalibration: (1) IP codification and innovation governance, (2) film industry, (3) pharmaceutical industry, (4) plant varieties and food industry, (5) automobile industry, and (6) peer production and the sharing economy.

On December 18-19, 2017, we held a sequel conference on Innovation, Economic Development and IP in India and China in Renmin University of China in Beijing. The seven study groups got together and discussed their initial findings. Two highranking judiciary members from India were invited and could not come due to internal rules. Their presence would have greatly enhanced our endeavor.

\footnotetext{
48 for Japan.

${ }^{3}$ We have chosen to focus on IT industry, rather than on information communication technology (ICT) industry, as India and China do not make a good pair for comparison. ICT includes (tele) communication, which is highly regulated in China and not open to competition, and innovation can only happen under constraints. In contrast, (tele)communication is less regulated in India. However, the present book has cited many studies that have targeted ICT and has to make necessary adjustments to make its statement focus on IT.
} 


\section{Methodology}

The project is an interdisciplinary research, in which legal, economic, and management acadmics corroborate and cross-fertilize. Equally important, this project is a cross-country study, in which we compare and contrast China and India. Last but not least, this is an undertaking to explore the relationship between innovation, economic development, and intellectual property in the actual context of India and China in six specific industries.

\section{Summary of the Findings of the Seven Study Groups}

\subsection{IP Codification and Innovation Governance}

IP laws as they now are stand generally quite in isolation from each other and lack overarching guiding principles to lead coherent legislation, interpretation, and application of individual IP provisions when dealing with similar or even the same topics, such as exhaustion, fair use, compulsory license of IP rights, damages, etc. ${ }^{4}$ Therefore, some national states have made efforts to codify IP laws either into one combined piece of law or into their respective Civil Law code, whether in existence or under construction. Admittedly, these countries are only a minority. Yet, they point out the challenging questions of why some of the same legal issues are dealt with differently across different IP laws within one country. Is it because of ignorance of other IP laws? Is it because of lobbying and under-table exchange of interests between lobbyists? Is it because of unspeakable foreign pressure? Can codification help alleviate the inconsistency or even arm-twisting of IP laws?

In addition, codification of IP laws has a China-specific meaning. China, although a latecomer in the realm of IP, has skyrocketing IP numbers in the last decade with all kinds of state funding and promotion schemes, to the extent that people start to fear for the alienation of IP laws and rights, the remaining space for free and fair competition, and the ramifications of comprehensive state intervention for the rule of law in China. Chapter 2 argues passionately for the codification of IP laws into the future Civil Law code of China, which could even offer some lessons for common law jurisdictions such as India.

\footnotetext{
${ }^{4}$ In Japan, however, the Trademark Act applies many articles of the Patent Act by analogy. For example, Article 13 provides:"(1)The provisions of Paragraphs (1) to (4) of Article 43, 43-2(2) and (3) of the Patent Act shall apply mutatis mutandis to an application for trademark registration... (2) The provisions of Articles 33 and paragraphs (4) to (7) of Article 34 (Right to obtain a patent) of the Patent Act shall apply mutatis mutandis to the rights deriving from an application for trademark registration." Article 35 further provides: "Article 73 (co-ownership), 76 (Lapse of patent rights in absence of heir), 97(1) (waiver), and 98(1)(i) and 98(2) (Effect of registration) of the Patent Act shall apply mutatis mutandis to trademark rights. In this case, the term "transfer (excluding those by general succession including inheritance)" in Article 98 (1)(i) of the Patent Act shall be deemed to be replaced with "division and transfer (excluding those by general succession including inheritance)."
} 
Chapter 3 looks into the most fundamental, yet often neglected, innovation infrastructure of India and China, namely, the constitution and its governance and power structure and distribution, and tries to identify its impact on their respective national innovation. This chapter rightly considers the wider setting, especially the shared value and power structure, which is highly relevant to the National Innovation System (NIS). India and China believe in socialism for modernization and have put socialism into the preamble of their constitutions but follow different schools of socialism, Fabianism for India and Marxism and Leninism for China.

Broadly speaking, the different versions of socialism substantially influence their ways of pursuing social revolution and social justice, which have different impacts on the social foundation of national innovation capacity. Following its non-violent strategy of civil disobedience for the independence movement, the social revolution after independence in India was also through non-violent means, mainly through universal adult suffrage. In pursuing social justice, India has institutionalized a credible set of checks and balances through electoral democracy plus independent judicial review, which on the other hand can slow down the process of innovation to a less optimal level.

However, China has followed Leninism, with violent revolution for social emancipation. The radical social transformation has helped China build a wider setting for innovation such as strong awareness of social equality, access to health and education, and rapid development of physical infrastructure. China's centralized power and policy-oriented administration make government responsive to and flexible in promoting innovation but at the costs of insecurity and uncertainty caused by the low level of rule-based institutionalization. Although India has lagged in most key economic indicators compared to China, the gradual social change has saved India from dramatic political turbulence and from uncontrolled economic and social transformation as well.

\subsection{IT Industry}

India and China make a perfect comparison pair in the area of IT industry, with each having its unique strength and potential for cooperation and synergy.

\subsubsection{Current Status China}

\section{IT Services and BPO/BPM}

The estimated revenue of both IT services (mobile apps, e-commerce, online gaming, cloud computing) and BPO/BPM for 2014 was US\$117 billion. ${ }^{5}$ That

\footnotetext{
${ }_{5}^{5}$ EU SME Centre/China-Britain Business Council, Sector Report, The ICT Market in China, 2015, available at: http://ccilc.pt/wp-content/uploads/2017/07/eu_sme_centre_report_-_the_ict_market_ in_china_update_-_july_2015.pdf
} 
figure is estimated to have more than doubled in 2018, reaching US\$276.3 billion. The main players are Tencent, Baidu, Alibaba, Netease, and JD.com, with market value estimated to have reached US\$ 1454.4 billion in $2018 .^{6}$

\section{Software ${ }^{7}$}

According to the Ministry of Industry and Information Technology of China (MIIT), the software industry can be divided into six segments, namely software products, system integration, operation services, embedded software, IT consulting, and IC design. Total revenue reached around US $\$ 815.8$ billion in the first 11 months of 2018 (up to November) and about US\$ 890 billion for the whole of 2018. Main players include Kingdee, ZTE, Neusoft, Founder Group, and Haier.

\section{Hardware}

China's hardware industry (also known as electronic information manufacturing industry) mainly includes computer manufacturing, communication equipment (like mobile phone) manufacturing, electronic components manufacturing, and electron device manufacturing. Total revenue of the industry is about US\$2.1 trillion in 2018. According to Canalys, China's client PC (including desktops, notebooks, two-in-ones and tablets) shipments will reach 88.6 million units and are expected to grow at a compound annual growth rate (CAGR) of $3.3 \%$ to reach 101.1 million units in 2019. Main players include Lenovo, Founder Group, Haier, Tsinghua Tongfang, and Xiaomi.

\section{IT as a Whole ${ }^{9}$}

The Chinese IT industry has developed at a high speed, and its structure was becoming more and more reasonable in 2017. Its main business income was over US\$ 2.8 trillion (including communication industry), marking an 11\% increase on a year-on-year basis. The total revenue of the software industry was about US $\$ 800$ billion and increased $13.9 \%$ compared with 2016 . The total revenue of the

\footnotetext{
${ }^{6}$ China Academy of Information Communication Technology: A Report on the Development Trend and Business Index of Chinese Internet Industry, available at: http://www.caict.ac.cn/kxyj/ qwfb/bps/201807/P020180710555374944625.pdf

${ }^{7}$ MIIT, The Economic Operation Situation of Chinese Software Industry in 2018 (January to November), available at: http://www.miit.gov.cn/n1146312/n1146904/n1648374/c6564586/content.html

${ }^{8}$ MIIT, A Research Report on the Comprehensive Development Index of Chinese Electronic Information Manufacturing Industry, available at: http://www.miit.gov.cn/n1146285/n1146352/ n3054355/n3057511/n3057518/c6512738/content.html, and http://www.miit.gov.cn/n1146285/ n1146352/n3054355/n3057511/n3057518/c6529823/content.html

${ }^{9}$ Digital China Union: Development Report of Chinese IT Industry for 2017, published at Chinese IT Leaders Summit Meeting (March 2018), pp. 17-18 (statistics of the whole Chinese IT industry for 2018 will not be available until March 2019).
} 
electronic information manufacturing industry, around US\$ 1.96 trillion, occupied a larger portion of the whole Chinese IT industry, about $71.1 \%$. Within the electronic information manufacturing industry, the total revenue of electronic components and electron devices grew at the highest speed and increased $17.8 \%$ and $18.2 \%$, respectively.

\section{India}

India Brand Equity Foundation $\left(\mathrm{IBEF}^{10}\right.$ ) classifies IT (or IT-enabled service industry (ITeS)) into four main components: IT services, BPO/BPM, software products and engineering services, and hardware. The 2018 Indian IT and ITeS Industry Report published by IBEF shows the following figures ${ }^{11}$ :

\section{IT Services}

Market size: US\$ 86 billion during 2018. Over $81 \%$ of revenue comes from the export market. BFSI (banking, financial services, and insurance) continues to be the major vertical segment of the IT sector. IT services made up around $51.7 \%$ of the Indian IT sector revenues in 2018.

\section{BPM}

Market size: US\$ 32 billion during 2018. Around 87\% of revenue comes from the export market. The BPM industry market size is to reach US\$ 54 billion by 2025. The BPM segment made up around $19.2 \%$ of the Indian IT sector revenues in 2018.

\section{Software Products and Engineering Services}

Market size: US\$ 33 billion during 2018. Over 83.9\% of revenue comes from exports.

The software products and engineering services segment grew $10.5 \%$ in 2017 . It made up around $19.8 \%$ of the Indian IT sector revenues in 2018.

\section{Hardware}

Market size: US\$ 15.4 billion in 2018. The domestic market accounts for a significant share. The segment made up around $9.3 \%$ of the Indian IT sector revenues in 2018.

\footnotetext{
${ }^{10}$ IBEF is a Trust established by the Department of Commerce, Ministry of Commerce and Industry, Government of India. IBEF's primary objective is to promote and create international awareness of the Made in India label in markets overseas and to facilitate dissemination of knowledge of Indian products and services.

${ }^{11}$ Available at https://www.ibef.org/download/it-ites-dec-2018.pdf
} 


\section{IT as a Whole}

Revenue reached US\$ 167 billion and exports stood at US\$ 126 billion in $2017-$ 2018. Export revenue from the digital segment forms about $20 \%$ of the industry's total export revenue, which is expected to grow 7-9\% year-on-year to US\$ 135137 billion in 2019. IT service exports are projected to add US\$ 10 billion in 2019 to reach US\$ 126 billion. Moreover, revenue from the digital segment is expected to form $38 \%$ of the total industry revenue by 2025. The IT industry employs nearly 3.97 million people. The computer software and hardware sector attracted cumulative foreign direct investment (FDI) inflows worth US\$ 32.23 billion between April 2000 and June 2018, which ranks second. India has extended tax holidays to the IT sector for software technology parks of India (STPI) and special economic zones (SEZs). Furthermore, the country is providing procedural ease and single window clearance for setting up facilities.

\subsubsection{Major Findings}

Chapters 4 and 5 have come to the following major findings.

Typical differences among IT companies in the two countries include:

1. Indian companies enjoy high international market penetration (high-end international markets in the IT service sector), while Chinese companies control lowand mid-end international markets in the manufacturing sectors.

2. Close connections between manufacturing and service sectors in China, which are lacking in India, may determine the potential competitiveness of companies in the industries.

3. China and India have followed different development paths in IT evolution. In China's case, it is forward integration, as it has combined the domestic and international markets. In India's case, it is backward integration, as it started from international markets and developed back to the domestic market.

4. Due to heavy involvement of Indian firms in IT software outsourcing arrangement by MNEs, the IP or patent resources are not important. This is especially true when compared with Chinese firms, which have much larger patenting volume (compared with other manufacturing sectors) in IT.

Reasons for the abovementioned differences probably lie in the following:

1. The Indian IT industry, both the hardware and software subsectors, would not have thrived without the strong government policy support, ranging from opening up for foreign investment well before the government officially adopted the policy of economic reforms in the early 1990s, duty-free import of computer systems for software export purposes, $100 \%$ foreign-owned enterprises for soft- 
ware exports operations were permitted, and the establishment of the software technology parks with government support. ${ }^{12}$

2. In India, national-level patent strategies in promoting public welfare-based litigation for Indian firms in the international community, maintaining a preventive patent database, etc. have protected Indian firms from patent snatching by nonIndian entities. Indian firms can also respond quickly and effectively to IP infringement claims by foreign companies through a highly protective IP system locally. In this regard, China seems to lag behind India, as China's National IP Strategy emphasizes more the creation and exploitation of IP rights by private sectors.

3. India's R\&D spending remained sluggish. Indian firms are weaker in self-owned IP assets in IT industries, in both hardware and software. In fact, based on the high volume of outsourcing arrangements by Indian firms, self-owned IP assets are not important for Indian companies in IT industries, particularly in the software sector. In general, the Indian IT industry has not contributed to indigenous technology development.

\subsection{Film Industry}

Film industry in India and China has grown despite piracy, and India can look at China to find IT means for delivery and payment of cinematographic content.

\subsubsection{Current Status}

\section{China}

After 40 years of market liberalization, China now has a booming film industry, despite high piracy. The number of produced feature films increased 10 times from around 40 in 1997 to 402 in 2007, and annual production ranked third worldwide after India and the USA. In 2015, the top ten private distribution companies made up $84.9 \%$ of the market in domestic films distribution, contributing RMB 22.98 billion in box office revenue and $52.1 \%$ of the total box office revenue in 2015. China's cinema is approaching a mega-industry. The number of cinema screens increased to 41,179 in 2016, which was for the first time more than those in the USA. All kinds of macro reforms have greatly improved the productivity and market adaptability of Chinese film production. Noteworthy is that China enacted in 2016 the Film Industry

\footnotetext{
${ }^{12}$ In 2000, India enacted the Information Technology Act (IT Act), which can mislead people into thinking this law is to promote IT technology. Rather, the IT Act is limited to providing legal recognition for transactions carried out by means of electronic data interchange and other means of electronic communication, commonly referred to as "electronic commerce." For an analysis of the relationship between the IT Act and Indian Copyright Act, see Raman Mittal, Actual Knowledge for Secondary Liability of Internet Intermediaries for Third-party Content Means Knowledge Based on A Court Order under Indian Information Technology Act in Kung-Chung Liu (edited) Annotated Leading Copyright Cases in Major Asian Jurisdictions, City University of Hong Kong Press, forthcoming 2019.
} 
Promotion Law to confirm and update the ongoing development directions of Chinese cinema in the form of law. ${ }^{13}$

Equally interesting is the film industry in the Special Administrative Region of China, Hong Kong, once the "Hollywood of the Far East" with 400 annual films, surpassing India, and 119 cinemas in 1993. Hong Kong's film industry experienced sharp decline in the last two decades with the number of cinemas dropping to only 47 (the second lowest per 100,000 persons/screen ratio compared to other major Asian cities) in 2015. It is now regaining its box office revenue, which increased to HK\$1947 million in 2016 and HK\$1853 million in 2017. However, the receipt increase is attributable to foreign, not domestic, films. In fact, foreign films contribute nearly $80 \%$ of the total revenue.

\section{India}

The Indian film industry is the world's largest in terms of films produced and tickets sold, third-largest in terms of box office size, and fastest-growing overall. Globally, Indian cinema enjoys popularity among the Indian diaspora, as well as among nonIndian populations in certain parts of Asia and Africa, and forms a component of India's global soft power. It is undeniable that a culture of piracy is prevalent throughout India. Pirated DVDs are openly sold in markets in Indian cities, while illegal file-sharing and downloading are common.

In 2012, India introduced an unwaivable right for authors of works, in particular authors of songs included in cinematograph films or sound recordings, to receive equal royalties accruing from exploitation of their works. It is important to note that there is no affirmative right to receive royalties in the Act. While the copyright can be assigned, the right to receive royalties cannot be assigned by the author to any person other than to the author's heirs or a copyright society for collection and distribution of royalties. The 2012 amendments were devised as reactionary measures to the denial of royalties and mismanagement of copyright societies in India by music labels. However, to date, copyright societies have refused to comply with the dictates of the amendments by all sorts of legal gambit (for more details, see Chap. 9).

\section{Screening of Indian Films in China and Chinese Films in India}

So far, Chinese movies have not made much headway into the Indian market. Indian movies as foreign movies are subject to a quota system (some follow the pattern of buyout of screening rights, others follow the profit-sharing arrangement) in China and were not much in demand. India and China signed an agreement on movie coproduction in 2014 that would indirectly boost the screening of Indian and Chinese films in the two countries. The breakthrough only came in 2017 with the film "Dangal," which has a record box office of RMB 1.299 billion. In 2018, Indian

\footnotetext{
${ }^{13}$ Article 29 of the Law imposes on cinemas a high quota of showing Chinese films no less than $2 / 3$ of the total show time. The United Kingdom enacted the Cinematograph Films Act of 1927 designed to stimulate the declining British film industry and to counter Hollywood's perceived economic and cultural dominance. It introduced a requirement for British cinemas to show a quota of British films, for a duration of 10 years. The act is generally not considered a success and was eventually repealed by the Films Act 1960; see https://en.wikipedia.org/wiki/Cinematograph_Films_Act_1927
} 
movies have become the second most popular foreign movies in China, only next to Hollywood. ${ }^{14}$

\section{Major Findings}

Chapters 6, 7, and 8 have come to the following major findings:

1. Film industries thrive in both India and China despite high piracy rates. In other words, film industries prospered with little or no copyright protection. More importantly, piracy did not kill the content industry in China and India, film and music alike, but probably helped in building the customer base and cultivating future demand, which might not be true for a small economy with a sophisticated audience such as Hong Kong. So long there is demand and appetite for movies, new ways of paying for movies will be schemed up, be it direct fee payment by buying tickets online, Internet service/bandwidth subscription, or indirect with ad sponsorship. The stronger demand there is for movies, the faster the emergence of new technical means for delivering content and fee-charging, as the Chinese film industry has shown how it can easily ride on the ubiquitous smartphones and smart TVs for this purpose.

2. Major Internet giants in China such as Baidu, Alibaba, and Tencent (the so-called BAT) have been swarming into the film industry, bringing with them big data, technology, funding, platforms, and fundamental changes to audiovisual services, transforming their business models from providing illegal content to legal but free (ad-sponsored) content and to legal and paid premium content. As a result, they not only provide instantaneous access to quality films and make enforcement of copyright against piracy easy but also fundamentally change consumers' behavior and habits in digital content consumption and help set up an industrial code or self-regulation for the digital film market. More and more, copyright law is playing a significant role in the furtherance of cinema industrialization. China is the future India in terms of copyright protection. In that regards, China's IT industry could very well lend a helping hand.

3. It is amazing to find out how the Chinese private film industry, including private film studios and private distribution chains, has managed to boom despite state ideology and a state-monopolized film production and distribution system within a short span of 40 years. The desire to create, share, and enjoy content, the foundation of freedom of expression, is simply unstoppable, even in the era of political left-leaning.

4. The Hong Kong story of how the director-centric production system, due mostly to the kung fu genre, has resulted in "guerrilla filmmaking," "script-butchering," and diluting the storyline, and how scriptwriters remain weak and unprotected caused by the lack of the collective bargaining right, is very illuminating for the film industry in any other economy. So is the overall poor infrastructure of the industry, particularly in terms of education, production, and distribution, which led also to the industry's decline. Moreover, different from other major

${ }^{14} \mathrm{http}: / /$ www.sohu.com/a/280668438_757761 
film-producing jurisdictions which grant the right of exploitation to the producer exclusively, such as Italy, France, Germany, China, Korea (per law), USA, and Japan (per practice), in Hong Kong a film is principally co-owned by the producer and the principal director. However, joint ownership is prone to conflicts between the interests of the producer and principal director, conflicts of applicable laws when the joint owners are from different jurisdictions - and disadvantageous for exploitation.

\subsection{Pharmaceutical Industry}

The importance of the pharmaceutical industry for India and China is beyond description. As it happens, the two "fellow sufferers ${ }^{15}$ " make a perfect comparison pair in the pharmaceutical industry as well. This time around, China can learn much from India.

\subsubsection{Current Status \\ India}

In India, domestic generic companies have been far ahead of the affiliates of foreign companies for the past three decades, ever since the generic companies were able to establish themselves as major players in the industry. The growth in sales registered by the leading generic producers in the early 1990s led to a complete transformation of the composition of market leaders. In 1994-1995, five of the ten top firms in terms of sales were the associates of foreign firms. But two decades later, nine of the top ten sellers were generic firms. Generic producers are the most profitable among all the leading sectors of the Indian industry. On average, they have registered double-digit profits since 2011, which could be much higher after including the data for the global operations.

The Indian pharmaceutical sector attracted US\$ 15.59 billion worth of FDI between 2000 and 2017. In Q2 2018, the Indian pharmaceutical sector posted private equity and venture capital investments of US\$ 396 million. Also, in 2017, India witnessed 46 mergers and acquisitions worth US\$1.47 billion. Over the past two decades, India's total trade in pharmaceutical products increased from less than US\$ 2 billion to more than US\$27 billion. This expansion came on the back of strong export performance, increased from just over US\$ 1 billion in 1996 to over US\$ 20 billion in 2016. India's place in the global market as supplier of cheap generics is confirmed by the pharmaceutical industry's growing presence in the market for formulations. Since the beginning of the current decade, exports of formulations have steadily increased, while bulk drug exports have stagnated. Between 2005 and 2016, bulk drug imports have increased more than threefold. China has emerged as the largest supplier of bulk drugs, supplying nearly two-thirds of Indian total imports.

\footnotetext{
${ }^{15}$ Both have a long history of traditional medicines and yet are both "lagging" behind in the development of patented new drugs.
} 
Market penetration of generic drugs increased rapidly after the enactment of the Hatch-Waxman Act in 1984. By the early years of the new millennium, generic drugs comprised more than $47 \%$ of the prescriptions filled for pharmaceutical products, up from 19\% in 1984. The Office of Generic Drugs of the US FDA reports that currently, 9 out of 10 prescriptions filled are for generic drugs. The USA is the single largest market for Indian formulations, taking up 39\% market share. This market expanded from less than $\$ 300$ million in 2005 to over $\$ 5.2$ billion in 2016.

\section{China}

In 2010 China's pharmaceutical industry achieved sales of US\$ 41.1 billion, making it the third largest in sales worldwide. In 2016, the business income of large-scale industrial enterprises in China's pharmaceutical industry reached RMB 2.96 trillion, an increase of $9.92 \%$ over the previous year. In 2015, China's biopharmaceutical manufacturing revenue from product sales was RMB 186.4 billion, and the total profit was RMB 31.0 billion, up $14.8 \%$ and $21.6 \%$, respectively, over the previous year. China is the second largest producer of active pharmaceutical ingredients (APIs) and the largest producer of penicillin and P-Lactam drugs and vitamins, accounting for $30 \%$ of the world's total output. The trade volume in pharmaceutical and health products in China in 2017 was US $\$ 116.76$ billion, including US\$60.8 billion in exports and US $\$ 55.88$ billion in imports. It enjoyed a US $\$ 4.9$ billion trade surplus, a $34.60 \%$ drop compared with the previous year.

More than $97 \%$ of the domestically produced drugs are generics. Most pharmaceutical companies in China mainly focus on producing generics with relatively low technical requirements and mature technologies. Serious overcapacity exists. The utilization rate of production capacity of tablets, capsules, powder injection, and water injection were less than $45 \%, 40 \%, 27 \%$, and 50\%, respectively. In China, pharma companies are small in scale, a substantial percentage of them are in deficit (15\% in 2009), and market concentration is low (the aggregate market share of the ten biggest companies (CR10) was $15.10 \%$ in 2004). As a result, pharmaceutical companies have an R\&D intensity of merely $1.77 \%$ on average, while the top ten pharmaceutical companies in the USA and India have an R\&D intensity of $35.3 \%$ and $15.9 \%$, respectively. In 2011, the cost of purchasing drugs by residents accounted for $50 \%-62 \%$ of the total health expenditure in China, much higher than the world average of $20 \%-30 \%$. In 2010, drugs revenue accounted for $42.1 \%$ of the total revenue of government-run medical institutions in China.

Among the pharmaceutical products currently manufactured in China, less than $3 \%$ have IP rights. The market of patented drugs is only RMB 12 billion, less than $1 \%$ of the domestic pharmaceutical market. The treatment of most infectious diseases such as chronic hepatitis B, AIDS, and other diseases depends on imported patented drugs, which are expensive. Almost all of the clinical standard medicines used in these areas of chronic diseases are patented drugs or patent-expired drugs. Nearly $90 \%$ of the patented drugs come from foreign enterprises.

However, annual patent application for polymorphic drugs in China has increased significantly in the last three decades. From 1985 to 2005, 2116 applications were from China, 651 were from the USA, and 432 were from Germany, India, and 
Switzerland. From 2005 to 2014, the total number of patent applications from China was 3009, an average of 301 applications each year, with the average annual growth rate at $147.9 \%$.

\section{Major Findings}

Chapters 10,11,12, and 13 have come to the following major findings:

1. The powerful constitutional obligations of the Indian state to improve public health and to guarantee every person and citizen of India the right to life and personal liberty while promoting its innovation ecosystem and safeguarding the legitimate business interests of inventors have been shaping the evolution of the Indian patent regime since India's independence in 1947, and all the way up to today, despite being listed either as a "Priority Foreign Country" or included on the "Priority Watch List" by the US Trade Representative (USTR) since 1989. Therefore, India is well known as a patent maverick. The refusal to grant product patents and the shortening of the period of patent protection for pharmaceutical process (5-7 years as against 14 years for other fields of technology in India's pre-TRIPS patent regime) allowed the generic pharmaceutical industry to grow starting from the 1970s. In contrast, China, despite having a constitutional mandate for the state to protect people's health, ${ }^{16}$ has been a naïve patent taker, not the least in the pharma industry, and never questioned the patent regime advocated by the international IP establishment.

2. After being updated to be TRIPS compliant in 2005, the Indian Patents Act continuously utilizes the leeway left by the TRIPS Agreement, including preventing evergreening of patented drugs, awarding compulsory license, retaining the pregrant opposition, and introducing the post-grant opposition, to better suit its national interests and developmental needs. It is therefore expected that India's pharma industry is poised to further outperform its Chinese counterpart.

3. India's experiences in legislation and judicial practice to promote the development of its domestic pharmaceutical industry deserve serious attention from China. The ingenious government legal maneuvering can serve as a good example for China to adjust its tactics in international IP negotiation and long-held blind faith in IP. Learning from India, China should start to provide its legal professionals with knowledge of global IP rules.

4. Although there is an increase in the number of patented drugs in the pharmaceutical industry in China, patents have made relatively low contribution to the industrial value, and IP held by Chinese firms is less competitive compared with that of foreign companies. In contrast, although major Indian companies are all producers of generic medicines, they continued to invest sizeable shares of their

\footnotetext{
${ }^{16}$ Article 21(1) of the PRC Constitution mandates that "The state develops medical and health services, promotes modern medicine and traditional Chinese medicine, encourages and supports the setting up of various medical and health facilities by the rural economic collectives, state enterprises and institutions and neighbourhood organizations, and promotes health and sanitation activities of a mass character, all for the protection of the people's health."
} 
sales turnover in R\&D, up from $1.5 \%$ at the end of the 1990 s, to $2 \%$ in 2000 2001, and to nearly $7 \%$ in 2015-2016. This aspect of the functioning was manifest in their patenting behavior. They were more active in filing patent applications in foreign jurisdictions, but significantly less so in domestic patenting.

\subsection{Plant Varieties and Food Security}

Food security is of high importance for the two most populous countries of India and China. To ensure food security, India enacted the National Food Security Act (NFSA) in September 2013, while the National People's Congress of China is now working on passing a bill on Food Security Law. Genetically engineered or modified crop plants are relevant for food security in India and China, as high-yielding crops can help overcome life-threatening food crises, achieve food surplus and feed their masses. India, with 11.4 million hectares $(6 \%)$, ranks 5th, and China, with 2.8 million hectares $(1 \%)$, ranks eighth among the 24 countries which planted biotech crops in 2017. ${ }^{17}$ During the first 21 years of commercialization of biotech crops, from 1996 to 2016, India has gained US\$21.1 billion sales and China US $\$ 19.6$ billion. $^{18}$

\subsubsection{Current Status}

India

India is the highest exporter of rice in the world. India was the ninth largest exporter of agricultural products in 2017 , and the sector constitutes a share of $13 \%$ of total exports of the country.

With the incorporation of gene technology, India has evolved from an importer to an exporter of cotton, and at present, India's average yield is around $500 \mathrm{~kg}$ of lint per hectare. India is now the biggest producer of cotton. The cotton production in India for 2017-2018 is around 365 lakh $(100,000)$ bales $(1$ bale $=170 \mathrm{~kg})$ and exports between 65 and 70 lakh bales. However, due to demand and consumption by local mills, India stands as the fourth largest exporter of cotton, behind the USA, Australia, and Brazil. As it stands, there are no food crops approved for use in India using GM technology. The Indian regulatory authority, the Genetic Engineering Approval Committee (GEAC), has approved Bt brinjal (eggplant) as being biosafe in 2017. However, its commercialization was not approved by the Ministry of Environment, Forests and Climate Change.

The IP framework for genetically engineered crops is prescriptive in its scope, and the recent judgments preclude protection for technologies for the development of genetically engineered plants under the existing provisions of the Patents Act, 1970. This would perhaps serve to disincentive players who have developed proprietary technologies from bringing their latest inventions for use by farmers in India.

\footnotetext{
${ }^{17}$ The International Service for the Acquisition of Agri-biotech App (ISAAA), Global Status of Commercialized Biotech/GM Crops in 2017, 5.

${ }^{18}$ Ibid., 8.
} 


\section{China}

In recent years, scandals involving illegal production and distribution of GM rice and its products have been consecutively exposed, which has led to mistrust among the public. As a response, the Food Safety Law was revised in 2015 to require that the production and distribution of GM food shall be clearly labeled. As far as GM foods are concerned, there are only regulations on transgenic agricultural products in general and labeling requirements provided by the Food Safety Law in particular. The lack of detailed legislation reflects China's evasive attitude toward this issue.

China has achieved remarkable results for the protection of new plant varieties since it promulgated and implemented the Regulations for the Protection of New Plant Varieties in 1997. In the revision of the Seeds Law in 2015, a section on the protection of new plant varieties was added. By 2016, the number of applications for new plant variety rights in China already ranked first in the world. From 1999 to June 2018, China approved a total of some 12,221 breeders' rights, of which 10,863 are for agriculture and 1,358 are for forestry (188 were obtained by foreign applicants from 9 countries, accounting for $13.84 \%$ of the total forestry breeders' rights). Chinese breeders mainly apply for breeders' rights in China and rarely pay attention to applying for breeders' rights abroad.

\section{Major Findings}

Chapters 14, 15, 16, and 17 have come to the following major findings:

1. Genes, proteins, promoters, enhancers, and chemicals in plants cannot get specific protection under the plant variety law and need to be protected under the patent regime. A recombinant DNA construct, which is neither a plant nor part thereof, nor a variety, can be protected under the patent regime and not under the plant variety law. Rights under the plant variety law and the rights granted under the patent law operate in completely different spheres. In India and China, what is protected under the patent law cannot be protected under the plant variety law and vice versa.

2. While India is still grappling with poverty, famine, shortage in food supply, and massive hikes in prices of basic foodstuffs, China has overcome these issues since 2007 at the latest by self-supply ${ }^{19}$. However, both countries have witnessed scandalous planting of GM plants and are in need of a robust regulatory framework to oversee the development of the genetic industry in agriculture.

\subsection{Automobile Industry}

Both India and China are catching up in the automobile industry in the last two decades. Comparatively speaking, the Indian automobile industry's absorption of global best practices has been slower than its Chinese counterpart. Strategies of firms in the Chinese auto industry provided a boost to technological learning more

\footnotetext{
${ }^{19}$ National Development and Reform Commission, Food Supply Abundant and Market Demand Effectively Satisfied in China (in Chinese), China Economic and Trade Herald, 2018, Issue 22, 63.
} 
quickly and broadly than in India, especially in the electric vehicle (EV) sector. India can benefit from learning from China.

\subsubsection{Current Status}

\section{China}

China has become the world's largest automotive producer and consumer, and the previous dominant strategy of the assemblage of imported foreign designs only has already given way to the strategy of indigenous innovation. No doubt, the indigenous car-makers are far from being global technology leaders, yet they are gradually becoming competitive in the global automobile market with the rise of EVs. China overtook the USA as the world's largest producer and consumer of EVs in 2015. EVs are to some extent an innovation with technological discontinuities, as motors and batteries are employed to replace the engines and gearboxes of the fossil fuel vehicles (FFVs). EVs are better able to interface with computer-based technologies, such as AI, the mobile Internet, and cloud computing. This has induced an explosive development of ICT technology applications on the car platform, creating an opportunity for China to pursue catch-up development.

The influx of new local entrants has fundamentally changed the rules of the game in China's car industry. Since 2001, as the new entrants gradually obtained regulatory approval, the entire production scale and the amounts of new products launched annually in China's car industry have skyrocketed, due to the leveraging effects created by new firms.

From 1999 to 2017, multinationals have submitted a total number of 87,089 patent applications in China, while new local entrants filed 66,043 and backbone stateowned enterprises (SOEs) and joint ventures (JVs) filed 32,227. Multinationals have the highest ratio of inventions, at $79.53 \%(69,265)$, and a low ratio of utility models, merely $3.06 \%$. The respective ratios for new local entrants are $32.84 \%$ and $50.24 \%$ and for backbone SOEs and JVs $20.55 \%$ and $57.72 \%$. The group of backbone SOEs and JVs exhibit obvious weakness in patent applications, as $58 \%$ of their patents fall in the category of utility model. The patent grant rate for the backbone SOEs and JVs is just $35.35 \%$, markedly below that of multinationals and new local entrants, which are $57.01 \%$ and $50.28 \%$, respectively. Most patent applications of multinationals are submitted by entities from their home countries, which indicates that their collaboration with JV partners in China remains highly irrelevant to their patent applications.

\section{India}

The automobile industry is one of the most important drivers of economic growth in India and one with high participation in global value chains. The automobiles produced in the country uniquely cater to the demands of low- and middle-income groups of the population. In 2017, India became the world's fourth largest automobile market, and the demand for Indian vehicles continues to grow in the domestic 
and international markets. India was the sixth largest producer of automobiles globally, with an average annual production of about 29 million vehicles in 2017-2018, of which about four million were exported. India is the largest tractor manufacturer, second largest two-wheeler manufacturer, second largest bus manufacturer, fifth largest heavy truck manufacturer, and eighth largest commercial vehicle manufacturer. The contribution of this sector to GDP has increased from $2.77 \%$ in 1992 1993 to about $7.1 \%$ and accounts for about 49\% of manufacturing GDP (2015-2016). It employs more than 29 million people (directly and indirectly). The turnover of the automobile industry is approximately US\$ 67 billion (2016-2017) and that of the component industry is US $\$ 43.5$ billion (2015-2016). The Indian industry accounted for $4.92 \%$ of vehicle production globally in 2017 (5.38\% of production in the cars segment and $3.48 \%$ of production in the commercial vehicles segment). India continues to be a net importer of auto components, with its trade deficit for auto components increasing from US\$ 210 million in 2004-2005 to US\$ 4.4 billion in 2009-2010 and US\$ 13.8 billion in 2015-2016.

As of today, the government encourages foreign investment and allows $100 \%$ FDI in the sector via the automatic route. The industry is fully de-licensed and free imports of automotive components are allowed. The Automotive Mission Plan 2016-2026 envisions that the Indian automotive industry will be among top three in the world in engineering, manufacture, and export of vehicles and auto components by 2026, growing in value to over $12 \%$ of India's GDP and generating an additional 65 million jobs.

\section{Major Findings}

Chapters 18 and 19 have come to the following major findings:

1. Government policy has played a pivotal role in the development of automobile industries in India and China. In China, the sectoral system of automobiles was mainly supported by two institutional pillars. The first pillar was strict regulation of entry permission, according to which all car products formally launched into the Chinese domestic market for sale must have prior permission from the MIIT to be listed in a regularly updated product catalogue. "Catalog-based regulation," a rigid legacy of the planned system, continues even after the transition to indigenous innovation. The second pillar is the "trading market for technology (TMFT)" policy since the 1980s. This strategy literally involves the trading of market access for technology with the multinationals possessing advanced technology, as acquisition of intangible IP assets on technologies would be less productive without the benefit of associated operational learning and expertise.

It was not until China's introduction of "the 1994 automobile industry policy" that car-making has been recognized as a national pillar industry. China's developmental strategy has transitioned to focusing on indigenous innovation by the National Medium- and Long-term Science and Technology Development Outline 
(2006-2020), which allows a group of new, local, innovative firms to enter the industry. Later on, the Chinese government has tabled a range of battery research and production projects and promulgated policies to encourage investment in the development and industrialization of EVs while subsidizing investments in infrastructure, especially a network of rechargeable devices.

The sum of subsidies provided by central and regional governments usually reaches $50 \%$ of the purchase price of EVs. It is only after 2013, witnessing how the new administration of $\mathrm{Xi}$ continues to stress indigenous innovation, that the backbone SOEs have begun to take innovation seriously.

Policy makers in China have decided to shift the policies again: the restrictions on foreign investment in China's EV industry have been removed in 2018; fully liberalized entry into the entire auto industry will be allowed in 5 years; the subsidy for purchasing EVs will be totally abolished by 2020 and has already been gradually reduced since 2017. The long-existing policy preferences for JVs will fade away.

In India, the growth of the automobile sector has been on the back of strong government support, which has helped it carve a unique path among the manufacturing sectors of India. Indian policy had favored the development of the commercial vehicles industry (light and heavy vehicles for public transport) as opposed to the development of passenger vehicles - considered luxury goods. By the early 1980s, the government had realized the need to develop the passenger vehicle segment and took decisions to allow FDI in automotive assembly in two major waves in 1983 and in 1993. This FDI was mainly "market seeking" in nature. Government policies such as import barriers and local content requirements contributed to the influx of FDI. Liberal policies of the 1990s led to the entry of new competitors and spillover benefits, especially on the technology side, and to increased expenditure on R\&D. The setting up of the National Automotive Testing and R\&D Infrastructure Project under the Automotive Mission Plan 2006-16 enabled the industry to achieve parity with global standards. Local content requirements or indigenization of up to $70 \%$ forced OEMs and their suppliers to make significant capital investments and created a chain of world-class component suppliers.

2. IP has played a relatively limited role in the development of the automobile industry in India and China. Unlike a science-based industry, the car-making industry is manufacturing-intensive and scale-intensive. Its key knowledge is embedded in manufacturing or design experience and does not appear in explicit forms such as utility/invention patents. Although patents are becoming increasingly important, a vast majority of "know-how" or "know-whom" kind of knowledge in this industry cannot be mastered through the acquisition of patents or patent licenses. Indeed, the technical trade or R\&D collaboration of many core businesses is through engineering services, design transfer (usually including engineering services), and component supplies. Hence, capacity building in this industry is a long-term process and may take many decades for latecomers. 
This is true for India and China. For example, without absorptive capacity for assessing and assimilating technologies, the backbone SOE Beijing Auto bought most of the IPs of SAAB in 2009; however, many of SAAB's high-value IPs had already been peeled off before the deal, as previously they had been traded for several rounds on the market. New entrants underwent a wide range of technical cooperation with international professional technology firms after the 1990s, played a more dominant role and were better able to identify technologies at the systemic level and explore more frontier issues.

In India, the number of patents granted to the seven leading Indian manufacturers between the period of January 1990 and July 2018 has increased, but not significantly. Tata's patents have increased the most, more than 5 times, but its absolute number has jumped from only 10 between 2001 and 2010 to 57 between 2011 and 2018.

\subsection{The Culture of Sharing and the Sharing Economy}

Both India and China consume goods and services in astronomic numbers and might face the threat of undersupply of goods and services and environmental crisis when they are supplied and consumed to heart's content of the Chinese and Indian people, as it would "burn up, heat up, eat up, plow up, choke up, and smoke up the planet. ${ }^{20}$ " The sharing economy as a new economy that creates sufficient supply through an effective mechanism for search and matching holds great promises for India and China. By sharing economy we refer to all business models facilitated by collaborative platforms that create an open marketplace for the temporary usage of goods or services often provided by private individuals, leading to the sharing of resources for their optimum utilization.

\subsection{Current Status}

\section{China}

With the maturing of Internet technology, mobile payment, logistics infrastructure, and huge demographic dividends, China's sharing economy has been leaping forward rapidly in recent years. In 2015 the size of the main sectors of China's sharing market amounted to about RMB 1,697.8 billion; the figure jumped to RMB 3,452 billion in 2016, an annual increase of $103 \%$ and accounting for GDP $4.6 \%$. In 2016, over 600 million people participated in sharing economy activities in China. The number of participants in the service sector was approximately 60 million, with approximately 5.85 million employees serving on platforms. The sharing economy is expected to account for $10 \%$ of GDP by 2020 and $20 \%$ by 2025 .

\footnotetext{
${ }^{20}$ Thomas Friedman, A Green New Deal revisited, New York Times, International edition, Jan. 11, 2019, 11.
} 


\section{India}

The Internet users in India are projected to increase from 331.77 million in 2017 to 511.89 million in 2022. The vast majority (>95\%) are mobile phone Internet users, and the young generations of Indians that have a preference to create, trade, swop, access, and share goods, services, and resources as opposed to owning them, building the powerful undercurrents for the sharing economy in India. Thus, in today's India, a variety of new businesses have sprung across a wide range of industries, such as transportation (e.g., Uber, Ola, ZipGo, BlaBlaCar, Smartmumbaikar.com, Didi Kuaidi), accommodation (Airbnb, Couchsurfing), work space sharing (WeWork, Regus, CoWrks, Awfis), retail commerce (e-Bay, Flipkart, Myntra, Jabong, Snapdeal), business loans (Biz2Credit), designer clothing (Rent It Bae), everyday clothing (Swishlist), and furniture and appliances (Fabrento, Rentickle, and Furlenco). ${ }^{21}$

Interestingly, even rural India has become the cradle of the sharing economy in a unique way. ${ }^{22}$ Thus, Mahindra \& Mahindra, one of the auto giants of India, created a sharing platform, Trringo, which allows farmers to rent equipments made by Mahindra (and even by its competitors) through placing a call. As a result, Mahindra has been able to increase its customer base, build brand awareness, and, drive rural prosperity by empowering farmers. Thus, sharing economy has been rapidly growing in India, particularly as the Gen Z consumers are discovering that it serves their goals and interests more effectively compared to owning the depreciating, underutilized assets.

In summary, sharing economy has been boosting the innovative entrepreneurship of bold new ideas in India, leading to - creation of disruptive businesses, optimal resource utilization, creation of new jobs, skill development, plus flexibility to operate at one's own convenience. Nevertheless, while India's GDP is expected to grow at $7.3 \%$ in $2018-2019,{ }^{23}$ accurate estimates of the contribution of sharing economy to the GDP of India or its growth are not yet readily available.

\section{Major Findings}

Chapters 20 and 21, more complementary in nature than providing comparable data on India and China, have come to the following major findings:

1. The sharing economy in India has not taken up the pace of China, probably due to lack of knowledge sharing, which is an integral part of the sharing economy. There are gender-based restrictions to knowledge as well as caste-based restrictions to knowledge. The National Intellectual Property Rights Policy and the Startup India Action Plan in 2016 have a bearing on shaping incentives for innovation and creativity in the sharing economy, but fail to take balanced and inclusive approaches.

\footnotetext{
${ }^{21} \mathrm{https} / / / \mathrm{www}$.liveinstyle.com/black-white-get-togethers/the-rise-of-the-sharing-economy

${ }^{22}$ https://www.bcg.com/en-us/publications/2017/strategy-accelerating-growth-consumer-products-hopping-aboard-sharing-economy.aspx

${ }^{23} \mathrm{https} / / / \mathrm{www}$.ibef.org/economy/indian-economy-overview
} 
2. The emergence of various business models and a series of legal risks and challenges that have restricted or are restricting the development of China's sharing economy, such as duplicated investment and vicious competition; opportunistic behavior, including the infringement of consumer rights and the distortion of reputation evaluation systems; and negative externality issues, could serve as good lessons for India.

Open Access This chapter is licensed under the terms of the Creative Commons Attribution 4.0 International License (http://creativecommons.org/licenses/by/4.0/), which permits use, sharing, adaptation, distribution and reproduction in any medium or format, as long as you give appropriate credit to the original author(s) and the source, provide a link to the Creative Commons license and indicate if changes were made.

The images or other third party material in this chapter are included in the chapter's Creative Commons license, unless indicated otherwise in a credit line to the material. If material is not included in the chapter's Creative Commons license and your intended use is not permitted by statutory regulation or exceeds the permitted use, you will need to obtain permission directly from the copyright holder.

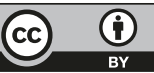

